\title{
Direitos / Rights
}

https://doi.org/10.21814/uminho.ed.36.25

\section{Priscilla Alderson}

Professor Emerita of Childhood Studies, University College London, United Kingdom 



\section{Direitos}

As discussões sobre direitos das crianças sugerem, frequentemente, que elas começaram em 1989 com a Convenção sobre os Direitos da Criança (CDC). No entanto, as crianças sempre partilharam os seus direitos com os adultos. 0 conceito de "direitos humanos" é aqui entendido como significando direitos que pertencem a todos os seres humanos, desde o nascimento. Isto acontece uma vez que todos os seres humanos partilham uma agência moral, o que não acontece com outras espécies (Bloom, 2014).

Algumas pessoas veem os direitos como um individualismo egoísta e com reivindicações gananciosas. Ainda assim, quer a CDC quer a Declaração Universal dos Direitos Humanos, de 1948, afirmam: "O reconhecimento da dignidade inerente e dos direitos iguais e inalienáveis de todos os membros da família humana é o fundamento da liberdade, justiça e paz no mundo". Reivindicar um direito é reconhecer que todos os outros têm uma reivindicação igual a esse mesmo direito: "os nossos direitos" e não "os meus direitos".

Para mostrar como os 42 artigos principais da CDC se aplicam a todas as crianças menores de 18 anos, eles serão revistos em relação aos bebés. Muitos bebés vivem em grande perigo: em famílias de refugiados que fogem da guerra, inundações, incêndios ou fome, e bebés nascidos de meninas que são crianças de rua ou que servem em exércitos rebeldes. Os bebés estão sobre-representados entre as famílias mais pobres em todos os lugares: aqueles que não têm comida saudável suficiente, que vivem em casas húmidas e frias ou em favelas, sem água potável ou recolha de lixo. Os seus pequenos corpos frágeis são mais facilmente danificados ou deformados e têm menor resistência a infeções. A cada ano, cerca de 4,5 milhões de bebés nascem mortos ou morrem cerca de um mês após o nascimento. A maioria destas mortes poderia ser evitada com melhores cuidados de saúde, mas os bebés também precisam de direitos, como soluções práticas poderosas para os erros estabelecidos na CDC. Todos os governos (exceto os EUA) ratificaram a Convenção, o que significa que se comprometem a implementar esses direitos e a informar, regularmente, a ONU, sobre o progresso na sua promoção (UN, 1989). Os direitos pertencem amplamente a três grupos parcialmente sobrepostos: provisão, proteção e participação. 
Os direitos de provisão dos bebés, previstos na $C D C$, incluem o direito à vida, a um nome e a uma nacionalidade. Isso permite que os governos reconheçam os bebés como seus cidadãos, com direito a serviços e apoios estatais. Os bebés têm direito aos cuidados básicos necessários ao seu bem-estar, aos cuidados de saúde mais qualificados possíveis, à água potável, à alimentação nutritiva e a um "padrão de vida adequado". Os bebés são mais saudáveis quando os seus pais e os profissionais que cuidam deles têm direito à educação e à informação.

Os bebés partilham todos os direitos de proteção, incluindo de: abuso e negligência; tortura, "tratamento cruel, desumano ou degradante"; invasão na sua vida familiar e na sua privacidade. Os direitos de privacidade deveriam, por exemplo, impedir os governos de pesquisar registos sobre bebés, mantidos por instituições de caridade e serviços de saúde, para encontrarem imigrantes e deportá-los. Todas as crianças têm direitos iguais contra discriminação e exploração, abuso sexual e venda ou tráfico.

No entanto, terão os bebés direitos civis e de participação? Os bebés participam nas suas comunidades locais, na vida cultural e civil assim que ouvem uma canção de embalar e são recebidos na sua igreja, mesquita, sinagoga ou templo. Para que os bebés possam pertencer a qualquer comunidade acolhedora, toda a família precisa de gozar dos direitos e liberdades de expressão e informação, de pensamento, consciência e religião, de associação e reunião pacífica e de liberdade de discriminação, com respeito ao contexto cultural da criança. Se estes direitos são gravemente negados, toda a família precisa de usufruir do direito civil a um processo legal que permita defender os seus direitos (Alderson, Killen \& Hawthorne, 2005).

O Artigo $12 .^{\circ}$ da CDC declara: "à criança com capacidade de discernimento o direito de exprimir livremente a sua opinião sobre as questões que the respeitem, sendo devidamente tomadas em consideração as opiniões da criança, de acordo com a sua idade e maturidade". Mesmo bebés prematuros podem formar e expressar opiniões sobre quando têm fome, estão cansados, contentes ou com medo, através dos seus sorrisos, choro e linguagem corporal, que informam os adultos atenciosos sobre as suas necessidades.

Diferentes estudos com bebés mostram que, desde o nascimento, estes parecem ter consciência da qualidade das relações humanas e, a partir dos 3 meses, da justiça e da gentileza. Eles parecem começar a compreender esses insights muito antes de poderem ser explicados aos bebés em palavras (Bloom, 2014). A natureza humana parece ser inatamente moral, bem 
como social, psicológica e física, razão pela qual os direitos humanos são tão importantes em todas as idades.

O advogado Conor Gearty (2011) acredita que os direitos humanos são "a arquitetura ética necessária para uma vida quaotidiana". Eles são "a única ideia contemporânea com verdadeiro apelo universal e progressivo" na atual "névoa pós-religiosa da supremacia do mercado" quando o lucro impera. Os direitos respeitam a dignidade de todos, através de estruturas de responsabilidade, equidade, do Estado de direito independente e da estrutura para trabalhar em prol de maior justiça entre indivíduos e Estados ricos e pobres. Portanto, respeitar os direitos dos bebés e ajudá-los a aprender a honrar os direitos iguais de todos como formas vitais de promover a paz e a justiça no mundo.

\section{Rights}

Discussions about children's rights often imply that they began in 1989 with the United Nations Convention on the Rights of the Child (UNCRC). Yet children have always shared rights with adults. The concept "human rights" is taken here to mean rights that belong to every human being, from birth. This is because humans all have a shared moral agency in ways that other species do not (Bloom, 2014).

Some people see rights as selfish individualism and greedy claims. Yet the UNCRC and the 1948 United Nations Declaration of Human Rights both state: "recognition of the inherent dignity and of the equal and inalienable rights of all members of the human family is the foundation of freedom, justice and peace in the world". To claim a right recognises that everyone else has an equal claim to that right: "our rights" not "my rights".

To show how the 42 main Articles in the UNCRC apply to every child under 18-years, they will be reviewed in relation to babies. Many babies live in great danger: in refugee families escaping from war, floods, fires or famine, and babies born to young girls who are street children, or who serve in rebel armies. Babies are over-represented among the poorest families everywhere: those who lack enough healthy food, who live in damp cold housing, or in baking slums without clean water or rubbish collections. Their small fragile bodies are most easily damaged or deformed, and they have the least resistance to infections. Each year, an estimated 4.5 million babies are stillborn or die within one month of birth. 
Most of these deaths could be prevented by better healthcare, but babies also need rights, as powerful practical remedies for wrongs as set out in the UNCRC. All governments (except the USA) have ratified the UNCRC, meaning they undertake to implement these rights and to report regularly to the UN on their progress in promoting them (United Nations, 1989). Rights broadly belong to three partly overlapping groups: provision, protection and participation.

Babies' UNCRC provision rights include their rights to life, to a name and a nationality. These enable governments to recognise babies as their citizens, with rights to state services and supports. Babies have rights to the basic care necessary for their well-being, to the highest attainable healthcare, to clean drinking water, nutritious food, and an "adequate standard of living". Babies are healthier when their parents, and professionals who care for them, have rights to education and information. Babies share all the protection rights, including those from abuse and neglect; torture, "cruel, inhuman or degrading treatment"; invasion into their family life and their privacy. Privacy rights should, for example, stop governments from searching records about babies, held by charities and health services, to find immigrants and deport them. All children have equal rights against discrimination and exploitation, sexual abuse and the sale or traffic of children.

Yet do babies have participation or civil rights? Babies participate in their local community, cultural and civil life as soon as they hear a lullaby, and are welcomed into their church, mosque, synagogue or temple. To enable babies to belong to any welcoming community, the whole family needs to enjoy rights and freedoms of expression and information, of thought, conscience and religion, of association and peaceful assembly, and freedom from discrimination, with respect for the child's cultural background. If rights are seriously denied, the whole family needs the civil right to due legal process to defend their rights (Alderson, Killen \& Hawthorne, 2005).

UNCRC Article 12 states: "the child who is capable of forming his or her own views [has] the right to express those views freely in all matters affecting the child, the views of the child being given due weight in accordance with the age and maturity of the child." Even premature babies can form and express views about when they are hungry, tired, contented or afraid through their smiles, cries and body language, which inform the caring adults about the babies' needs. 
Studies with babies show that, from birth, they seem to begin to be aware of the quality of human relationships and, from 3 months onwards, of justice and kindness. They seem to start to understand these insights long before they can be explained to the babies in words (Bloom, 2014). Human nature seems to be innately moral as well as social, psychological and physical, which is why human rights are so important at every age.

The lawyer Conor Gearty (2011) believes human rights are "the ethical architecture necessary to decent everyday life". They are "the only contemporary idea with true universal and progressive appeal" in the present "post-religious haze of market supremacy" when profit rules. Rights respect everyone's dignity through structures of accountability, equity, the independent rule of law, and the framework for working towards greater justice between rich and poor individuals and states. So to respect babies' rights and help them to learn to honour the equal rights of all are vital ways to promote peace and justice in the world.

\section{Referências / References}

Alderson, P., Killen, M. \& Hawthorne, J. (2005). The participation rights of premature babies. International Journal of Children's Rights, 13, 31-50.

Bloom, P. (2014). Just Babies: The Origins of Good and Evil. New York: Broadway Books.

Gearty, C. (2011). The rights future: Exploring dignity, accountability, equality and commitment. Online. http://therightsfuture.com/about/

United Nations. (1989). Convention on the Rights of the Child, http://www.ohchr.org/EN/ Professionallnterest/Pages/CRC.aspx and Committee on the Rights of the Child, https://ohchr. org/EN/HRBodies/CRC/Pages/CRCIndex.aspx. 